\title{
Serotonin transporter gene polymorphisms in patients with chronic tension-type headache: A preliminary study
}

\author{
Akcali Aylin, Tataroglu Cengiz ${ }^{1}$, Erdal Emin ${ }^{2}$, Aydin Neriman ${ }^{3}$, Pehlivan Sacide ${ }^{4}$ \\ Department of Neurology, Gaziantep University, ${ }^{1}$ Department of Neurology, Celal Bayar University, ${ }^{2}$ Department of Medical Biology and \\ Genetics, Mersin University, ${ }^{3}$ Department of Public Health, Gaziantep University, ${ }^{4}$ Department of Medical Biology and Genetics, Gaziantep \\ University, School of Medicine, Turkey
}

\begin{abstract}
Background and Objectives: This study is designed to understand the pathophysiology of one of the most serious health problems, chronic tension-type headache (CTTH). Two polymorphic sites in serotonin transporter protein gene attracted much interest. These are: the variable number of tandem repeats (VNTR) and 5'-flanking promoter region (5-HTTLPR). Materials and Methods: VNTR and 5-HTTLPR polymorphisms were investigated in $126 \mathrm{CTTH}$ patients and 138 healthy control subjects. The patients were being treated with amitripytyline or citalopram or sertraline (SSRI). The polymerase chain reaction (PCR) method was used to investigate the polymorphisms in the serotonin transporter protein gene. Results: There were no statistically significant results based on the 5-HTTLPR gene alleles, however, STin 2.12/12 genotype and STin 2.12 allele were seen to predominate the control group. In order to investigate the combined effect of the two polymorphic loci on the 5-HTT gene expression, samples were separated into nine groups. Genotypes (S/S-12/10) and (L/S-12/10) displayed statistically significant frequency in the CTTH group than in the control group. No significant differences were noticed between the 5-HTTLPR and VNTR haplotype groups and success in treatment. Conclusion: It is possible to make reliable comparisons and hypothesis about the homozygous and/or heterozygous presence of S and STin 12/10 alleles which may be in interaction with CTTH. On the other hand, the presence of homozygous $L$ and STin 12 alleles may play a protective role against CTTH. It is also possible that heterogeneity among diseases showing the same clinical research will require a lot of effort for individual identification.
\end{abstract}

Key words: 5-flanking promoter region, chronic tension-type headache, haplotypes, serotonin transporter protein gene, a variable number of tandem repeats

Primary headaches constitute a major health problem and this is why there has been an increasing interest in the genetic associations of these widespread disorders within the last couple of years. Chronic tension-type headache (CTTH) occurs on at least 15 days in a month for up to three months and requires a visit to the family practitioner, neurologists and other physicians. ${ }^{[1]}$ A recent study has shown that CTTH is one of the most serious reasons for the loss of productive effort. ${ }^{[2]}$ A Danish study showed that 12\% of employed subjects with CTTH had missed one or more days of work in a given year because of headache. The total loss of workdays per year due to tension-type headache in the general population was estimated to be 820 days in 1000 persons. ${ }^{[3]}$ Studies in Turkey showed that CTTH had a higher impact on loss of productivity and drug costs, going on to have a larger economic impact. ${ }^{[4]}$

In order to address the role of the serotonergic system on pathophysiologic mechanisms of CTTH, some studies have been published about one of the key modulators: serotonin transporter protein..$^{[5-7]}$

Serotonin is uptaken from the synaptic space regularly with a 5-hydroxytryptamine transporter (5-HTT) and returned to the neurotransmitter pole to be used again in succession..$^{\left[{ }^{8,9]}\right.}$ Serotonin transporter protein (5-HTT) is encoded by the single gene SLC6A4 on Chromosome 17q12. ${ }^{[10]}$ Two polymorphic sites in 5-HTT gene grabbed interest: a variable number of tandem repeats (VNRT) of 17-bp repeats in intron two as it has several alleles such as STin 2.7, STin 2.9, STin 2.10, STin 2.11, STin 2.12 and an insertion/deletion in 5'-flanking promoter region (5-HTT gene-linked polymorphic region-5HTTLPR) creating a short (S) and a long (L) allele. The 5-HTTLPR polymorphism is situated in a GC-rich region composed of 20-23 bp repeating units. The $S$ and L alleles have 14 and 16 repeat-elements respectively. ${ }^{[11,12]}$ The short form of this variant, "S" is associated with lower basal and induced transcriptional efficiency of the 5-HTT gene promoter, resulting in lower serotonin uptake activity, when compared with the long form "L". ${ }^{[10]}$ Further studies revealed analogous functional consequences of 5-HTTLPR on 5-HTT expression in brain cells and tissues. ${ }^{[13,14]}$ Some studies indicate that 
the 12-repeat allele is associated with higher enhancerlike properties for the transcription of the 5-HTT gene than 10-repeat allele while other studies have found no associations. ${ }^{[14-18]}$ There is some evidence to suggest that the 5-HTT gene may be involved in the pathogenesis of migraine with aura and CTTH and both polymorphic regions have been objects for studies. These results support the hypothesis that drugs primarily acting via 5-HTT inhibition, such as SSRIs and serotonin agonists may be effective in the pharmacotheraphy of headaches.

The aim of this study is to investigate the possible role of 5-HTTLPR and VNTR polymorphisms individually and in combination in CTTH patients. Moreover, we aim to evaluate the relationship between the clinical response of the drugs and the serotonin transporter (5-HTT) gene polymorphisms.

\section{Materials and Methods}

One hundred and twenty-six CTTH patients (109 females and 17 males, mean age of $38 \pm 18.24$ years) and 138 control subjects (117 females and 21 males, mean age of $23.29 \pm 6.67$ years) were included in this prospective study. The operational diagnostic criteria of the International Headache Society (IHS) were used to evaluate patients with CTTH. ${ }^{[1]}$ Chronic tension-type headache is typically bilateral, pressing or tightening in quality and occurs on $\geq 15$ days/ month on an average of $\geq 3$ months, lasting hours or continously. Patients and control groups with episodic migraine or features of nausea, vomiting, photophobia or phonophobia over a period of at least three months were excluded. All participants were interviewed in an outpatient clinic and examined neurologically by a neurologist before being followed for eight weeks. The control group consisted of healthy people having no type of headache or any other disorder.

There were no significant differences in the baseline demographics between the study and the control groups. All study subjects signed informed consent before participating in the research. The CTTH and control group subjects were of the same ethnicity, but none were of the same family.

The CTTH patients had not used SSRI (serotonin reuptake inhibitors) or amitripytyline and were not drug abusers. The treatment consisted of randomized amitripytyline $10 \mathrm{mg} /$ day or SSRI (citalopram $20 \mathrm{mg}$ / day or sertraline $50 \mathrm{mg} /$ day) but none had placebo. Comparisons between the groups were assessed by visual analogue scale (VAS) for outcome. Control visits were done once a month and in every visit VAS scores were asked. Responders were defined as those with a decrease in VAS by $50 \%$ since the beginning.

\section{DNA extraction and analysis}

With a written informed consent, a blood sample was drawn from each individual. The DNA was extracted from the whole blood using a genomic DNA purification kit (MBI Fermentas, Cat:12200, USA). An insertion/ deletion polymorphism (5-HTTLPR) in the promoter region of the serotonin transporter gene was typed by PCR using the Lesh et al., method. ${ }^{[11]}$ A variable number of tandem repeats (VNTR) polymorphism in intron 2 of the 5-HTT gene was typed by PCR using the Cook et al., method. ${ }^{[19]}$ Genotyping was based upon independent scoring of the results by two reviewers who were unaware of case/control status.

\section{Statistical analysis}

In the analysis of the combination of 5-HTTLPR genotype, the rates of the long (L) and short (S) alleles and 5-HTT gene VNTR genotype 12 and 10 alleles were compared between the CTTH and control groups. ${ }^{[20]}$ The genotypes were compared with the efficacy of the drugs according to the VAS results. $\chi^{2}$ tests, Fischer's exact test and Kolmogrow Smirnow test were included where applicable. ANOVA was used to evaluate differences in the VAS. SPSS standard software (version 11.0) was used in all analyses and $P<0.05$ was considered as significant.

\section{Results}

The observed genotype counts were not deviated significantly from those expected according to the Hardy Weinberg Equilibrium ( $P>0.05$ ) [Table 1]. The functional polymorphisms of the 5-HTTLPR gene and VNTR were analyzed for all study subjects [Table 1]. One of the major VNTR alleles, STin 2.9, was present in two patients and was included in the STin 2.10 group. The $\mathrm{L}$ allele and the $\mathrm{S}$ allele, the 12 allele and the 10 allele with genotype frequencies for both the CTTH and the control groups are presented in Table 1. There were no statistically significant results between each group according to 5-HTTLPR gene alleles, but STin 2.12/12 genotype and STin 2.12 allele predominated in the control group. In order to investigate the combined effect of the two polymorphic loci on the 5-HTT gene expression, samples were separated into nine groups: Genotypes (L/L-12/12), (L/L-12/10), (L/L-10/10), (L/S12/12), (L/S-12/10), (L/S-10/10), (S/S-12/12), (S/S-12/10), (S/S-10/10). Genotypes (S/S-12/10) and (L/S-12/10) reached statistically significant frequency in the CTTH group than in the control group $\left(\chi^{2}=5.64 \mathrm{P}=0.017\right.$, $\chi^{2}=3.89 \mathrm{P}=0.048$ respectively). The combination of genotype frequencies in the CTTH and the control groups are summarized in Table 2. Duration and frequency of headache significantly improved after eight weeks of treatment $(P<0.001)$. No significant difference was noticed between 5-HTTLPR and VNTR 


\begin{tabular}{|c|c|c|c|c|c|c|}
\hline & Genotype & СТTH $n=126(\%)$ & Control $n=138(\%)$ & $P$ & Control HW* - P & ССТH HW* $-P$ \\
\hline \multirow[t]{3}{*}{ 5-HTTLPR } & LL & $25(20)$ & $33(24)$ & 0.425 & 0.076 & 0.96 \\
\hline & LS & $62(49)$ & $58(42)$ & 0.242 & & \\
\hline & SS & $39(21)$ & $47(34)$ & 0.591 & & \\
\hline \multirow[t]{2}{*}{ Allele } & $\mathrm{L}$ & $112(44)$ & $124(45)$ & & & \\
\hline & S & 140 (56) & $152(55)$ & 0.911 & & \\
\hline \multirow[t]{3}{*}{ VNTR } & $10 / 10$ & $15(12)$ & $15(11)$ & 0.791 & 0.312 & 0.069 \\
\hline & $12 / 10$ & $70(56)$ & $53(38)$ & $0.005^{*}$ & & \\
\hline & $12 / 12$ & $41(32)$ & $70(51)$ & $0.003^{*}$ & & \\
\hline \multirow[t]{2}{*}{ Allele } & 10 & $100(44)$ & $83(30)$ & & & \\
\hline & 12 & $152(56)$ & $196(70)$ & $0.020^{*}$ & & \\
\hline
\end{tabular}

${ }^{*} \mathrm{HW}$, Hardy-Weinberg equilibrium, $P<0.05$ : Significant

\begin{tabular}{|c|c|c|c|c|c|}
\hline \multirow{2}{*}{$\begin{array}{l}\text { Genotype } \\
\text { combinations }\end{array}$} & \multicolumn{2}{|c|}{ CTTH } & \multicolumn{2}{|c|}{ Control } & \multirow[t]{2}{*}{$\chi^{2} / P$} \\
\hline & $n$ & $\%$ & $n$ & $\%$ & \\
\hline L/L-12/12 & 7 & 5.38 & 16 & 12.31 & $3.02 / 0.08$ \\
\hline L/L-12/10 & 7 & 5.38 & 12 & 8.69 & $0.97 / 0.324$ \\
\hline L/L-10/10 & 11 & 8.47 & 5 & 3.85 & $3.02 / 0.08$ \\
\hline L/S-12/12 & 16 & 12.31 & 22 & 16.92 & $1.01 / 0.315$ \\
\hline L/S-12/10 & 42 & 32.31 & 31 & 23.85 & $3.89 / 0.0485^{\star}$ \\
\hline L/S-10/10 & 4 & 3.08 & 5 & 3.85 & $P=0.556^{\ddagger}$ \\
\hline $\mathrm{S} / \mathrm{S}-12 / 12$ & 18 & 13.85 & 32 & 24.62 & $3.40 / 0.065$ \\
\hline S/S-12/10 & 21 & 16.15 & 10 & 7.69 & $5.64 / 0.017^{*}$ \\
\hline S/S-10/10 & - & - & 5 & 3.85 & - \\
\hline Total & 126 & & 138 & & \\
\hline
\end{tabular}

*Significant $(P<0.05)$; *Fisher

genotype groups and success in treatment due to 50\% decrement in VAS scores $(P=0.996)$. There were no significant differences between genotypes and severity of CTTH (VAS $\geq 7$ ) either ( $P=0.784)$. There was no difference between drugs and response to treatment $\left(\chi^{2}=0.22, P=0.636\right)$.

\section{Discussion}

Tension-type headache studies have not been conducted as much as migraine studies. Recently, the ICHD-II (The international classification of headache disorders) revised the criteria incorporating many developments and presented an effective classification. ${ }^{[1]}$ In comparison to the general population, first degree relatives of CTTH patients had three times more risk of CTTH. This result supports the importance of genetic factors in CTTH. ${ }^{[21]}$

Epidemiological studies on tension-type headache frequency and genetic polymorphisms may lighten the risk factor of 5-HTT gene polymorphism. The presence of $S$ allele has been found to have less serotonin activity and serotonin uptake. ${ }^{[7,11,12]}$ In Chinese and Korean study groups, $\mathrm{S}$ allele has been found two or three times more frequently than L allele and depressed patients with L allele showed better response to SSRIs. ${ }^{[18,22,23]}$ Two studies from the same population showed no significant association between migraine frequency and $S$ allele, but demonstrated a difference in the genotype distribution of $S$ allele in patients with CTTH. ${ }^{[6,18]}$ Besides, in the same studies, patients with S allele had significantly more frequent attacks of migraine than those with $\mathrm{L}$ allele. ${ }^{[18]}$ The 5-HTTLPR S allele has been associated with slower response to various antidepressant treatments ${ }^{[24-27]}$ though not univocally. ${ }^{[28]}$ There are controversial results with association of $S$ allele and migraine. ${ }^{[29,30]}$ According to our results, genotypes are not observed in association with response to SSRIs and TCAs. In our study, $\mathrm{S}$ allele was more frequent both in the CTTH and control groups (56\%, 55\% respectively), but not as much as the frequency of the Korean people with $S$ allele at the rate of $86 \%$. $^{[19]}$ The VNTR polymorphism in native expressing cells showed no significant effect on 5-hydroxyindoleacetic acid level in the cerebrospinal fluid, but revealed a higher level of norepinephrine metabolite in STin 12/12 group. ${ }^{[31]}$ STin 2.12 has been found to be associated with the risk of anxiety disorders and we know that tension-type headache has been seen in combination with anxiety disorders. ${ }^{[32-34]}$ Another study suggested that migraine patients with or without aura had an overrepresentation of STin 2.12. ${ }^{[35]}$ Varied results of these polymorphism studies let us think that other factors like enzymes, serotonin receptors and polymorphisms may play a role in the serotonergic system. According to our results, predominance of STin 2.12/12 genotype and STin 2.12 allele in the control group may postulate that susceptibility to CTTH had a genetic component. The association between the VNTR polymorphism and CTTH deserves further evaluation.

Although there is no statistical difference between the efficacy of drugs and the genotypes, the benefit on headache duration and severity was significant $(P<0.05)$. Clinical response to SSRIs and TCAs may indicate the serotonergic dysfunction in the central nervous system of the CTTH patients. Independence of the efficacy of drugs from the genotypes means that studying a single factor involved in serotonergic activity may not be enough to end up this subject. An increased knowledge of the genetic risk factors will give an opportunity to understand the pathogenesis of CTTH, which is therefore expected to enable clinicians to select people who will have a high risk of CCTH and benefit from treatment. As mentioned above, all of the 
studies were aimed at looking into the effect of a single polymorphism of 5-HTT function separately. However, it is much more informative to analyze markers in a region of interest simultaneously. Genotype analysis should be tested in large clinical samples in order to increase knowledge about CTTH susceptibility. It is also possible that the heterogeneity among diseases showing the same clinical research will require time and effort for individual identification.

Although these two polymorphisms have been investigated individually and extensively for association with migraine and psychological symptoms, to our knowledge, there are no reported studies on the combined effect of 5-HTTLPR and VNTR genotypes on CTTH. According to our results, we may suggest that the presence of one/two S allele(s) with STin 2.12/10 may be responsible for having CTTH. Furthermore, the results revealed that the homozygous $S$ group with STin 2.12/10 was more significant with $\mathrm{P}=0.017$ than the heterozygous $\mathrm{S}$ group with STin $2.12 / 10$. At this point, we may be able to make reliable comparisons and hypotheses on the homozygous and/ or the heterozygous presence of S and STin10 alleles; and their possible interaction with the CTTH. In L/L$10 / 10$ group, the results may indicate that the present homozygous STin 2.10 allele does not act as a dominant allele in combined effect $(P=0.08)$. However, STin $12 / 10$ genotype may be in interaction with the $S$ allele in CTTH patients. This datum supports that the action of genetic variation at the VNTR locus is influenced by other genetic and environmental influences. On the other hand, the presence of homozygous L and STin12 alleles may play a protective role against CTTH. Recently, a new possible combined effect of alleles on 5-HTT expression is indicated as low-expressing (short [S], 10); but high-expressing (long [L], 12) in schizophrenics. VNTR polymorphism 10 allele has acted as the dominant low-expressing allele in genotypes and reduced relative 5-HTT gene expression on lymphoblast. ${ }^{[36]}$ In our results, combined genotypes S/S-12/10 and L/S-12/10 had significant interaction with the CTTH group.

Guidelines for complex diseases recommend that 500 samples for patients and controls will give sufficient results. Larger study groups will give more reliable results. In this study the CTTH is compared with healthy subjects. Another study dealing with the comparison of chronic headache with non-chronic headache or other chronic illnesses may be a better way. Another limitation of this study is that the anxiety and depression traits were not screened and we could not analyze them with genotypes.

In conclusion, to our knowledge, this is the first study resulting with modest evidence for a possible combination of the 5-HTTLPR and VNTR polymorphisms with CTTH. Further large, cross-ethnic studies including psychiatric assessment are needed to determine whether alterations in serotonin gene expression are involved in CTTH.

\section{References}

1. Headache classification subcommittee of the international headache society. The International Classification of Headache Disorders. $2^{\text {nd }}$ ed. Cephalagia 2004;24:39-40.

2. Stovner LJ, Zwart JA, Hagen K, Terwindt GM, Pascual J. Epidemiology of headache in Europe. Eur J Neurol 2006;13:333-45.

3. Rasmussen BK, Jensen R, Olesen J. Impact of headache on sickness absence and utilisation of medical services: A Danish population study. J Epidemiol Community Health 1992;46:443-6.

4. Karli N, Zarifoğlu M, Ertafş M, Saip S, Oztürk V, Biçakçi S, \& al. Economic impact of primary headaches in Turkey: A university hospital based study: part II. J Headache Pain 2006;7:75-82.

5. Tomkins GE, Jackson JL, O'Malley PG, Balden E, Santoro JE. Treatment of chronic headache with antidepressants: A meta analysis. Am J Med 2001;111:54-63.

6. Park JW, Han SR, Yang DW, Kim YI, Lee KS. Serotonin transporter protein polymorphism and harm avoidance personality in migraine without aura. Headache 2006;46:991-6.

7. Juhasz G, Zsombok T, Laszik A, Gonda X, Sotonyi P, Faludi G, \& al. Association analysis of 5-HTTLPR variants, 5-HT2a receptor gene 102T/C polymorphism and migraine. J Neurogenet 2003;17:231-40.

8. Gelernter J, Kranzler H, Coccaro EF, Siever L.J, New AS. Serotonin transporter protein gene polymorphism and personality measures in African American and European American subjects. Am J Psychiatry 1998;155:1332-8

9. Serretti A, Catalano M, Smeraldi E. Serotonin transporter gene is not associated with symptomatology of schizophrenia. Schizophr Res 1994;35:33-9.

10. Lesch KP, Balling U, Gross J, Strauss K, Wolozin BL, Murphy DL. Organisation of the human serotonin transporter gene. J Neurol Transm Gen Sect 1994;95:157-62.

11. Lesch KP, Bengel D, Heils Sabol SZ, Greenberg BD, Petri S, Benjamin J, \& al. Association of anxiety-related traits with a polymorphism in the serotonin transporter gene regulatory region. Science $1996 ; 274$ : 1527-31.

12. Heils A, Teufel A, Petri S, Stober G, Riederer P, Bengel D, \& al. Allelic variation of human serotonin transporter gene expression. J Neurochem $1996 ; 66: 1-4$

13. Mortensen OV, Thomassen M, Larsen MB, Whittemore SR, Wiborg O. Functional analysis of a novel human serotonin transporter gene promoter in immortalized raphe cells. Brain Res Mol Brain Res 1999;68: 141-8.

14. Little KY, McLaughlin DP, Zhang L, Livermore CS, Dalack GW, McFinton PR, \& al. Cocaine, ethanol and genotype effects on human midbrain serotonin transporter binding sites and mRNA levels. Am J Psychiatry 1998;155:207-13.

15. Borroni B, Brambilla C, Liberini P, Rao R, Archetti S, Gipponi S, \& al. Functional serotonin 5-HTTLPR polymorphism is a risk factor for migraine with aura. J Headache Pain 2005;6:182-4.

16. Kim WK, Kim HS, Kim WJ, Lee KY, Park H, Kim CH, \&al. Serotonin transporter gene polymorphism and migraine in the Korean population. Headache 2005;45:1056-60.

17. Marziniak M, Mossner R, Schmitt A, Lesch KP, Sommer C. A functional serotonin transporter gene polymorphism is associated with migraine with aura. Neurology 2005;64:157-9.

18. Park JW, Kim JS, Lee KL, Kim YI, Lee KS. Serotonin transporter polymorphism and harm avoidance personality in chronic tension-type headache. Headache 2004;44:1005-9.

19. Cook EH Jr, Courchesne R, Lord C, Cox NJ, Yan S, Lincoln A, \& al. Evidence of linkage between the serotonin transporter and autistic disorder. Mol Psychiatry 1997;2:247-50.

20. Available from: http://ihg2.helmholtz-muenchen.de/cgi-bin/hw/hwa1.pl.

21. Ostergaard S, Russell MB, Bendtsen L, Olesen J. Comparison of first degree relatives and spouses of people with chronic tension headache. 
BMJ 1997;314:1092-3.

22. Ng CH, Eastel S, Tan S, Schweitzer I, Ho BK, Aziz S. Serotonin transporter polymorphisms and clinical response to sertraline across ethnicities. Prog Neuropsychopharmacol Biol Psychiatry 2006;30:953-7.

23. Arias B, Catalan R, Gasto, Gutierrez B, Fananas L. 5-HTTLPR polymorphism of the serotonin transporter gene predicts non-remission in major depression patients treated with citalopram in a 12 -weeks follow up study. J Clin Psychopharmacol 2003;23:563-7.

24. Benedetti F, Serretti A, Colombo C, Campori E, Barbini B, di Bella D, e al. Influence of a functional polymorphism within the promoter of the serotonin transporter gene on the effects of total sleep deprivation in bipolar depression. Am J Psychiatry 1999;156:1450-2.

25. Pollock BG, Ferrell RE, Mulsant BH, Mazumdar S, Miller M, Sweet RA, \& al. Allelic variation in the serotonin transporter promoter affects onset of paroxetine treatment response in late-life depression. Neuropsychopharmacology 2000;23:587-90.

26. Smeraldi E, Zanardi R, Benedetti F, Di Bella D, Perez J, Catalano M. Polymorphism within the promoter of the serotonin transporter gene and antidepressant efficacy of fluvoxamine. Mol Psychiatry 1998;3: 508-11.

27. Zanardi R, Benedetti F, Di Bella D, Catalano M, Smeraldi E. Efficacy of paroxetine in depression is influenced by a functional polymorphism within the promoter of the serotonin transporter gene. J Clin Psychopharmacol 2000;20:105-7.

28. Kim DK, Lim SW, Lee S, Sohn SE, Kim S, Hahn CG, Carroll BJ. Serotonin transporter gene polymorphism and antidepressant response. Neuroreport 2000;11:215-9.

29. Lea RA, Dohy A, Jordan K, Quinlan S, Brimage PJ, Griffiths LR. Evidence for allelic association of the dopamine beta-hydroxylase gene
(DBH) with susceptibility to typical migraine. Neurogenetics 2000;3: $35-40$.

30. Monari L, Mochi M, Valentino ML, Arnaldi C, Cortelli P, De Monte A, \& al. Searching for migraine genes: Exclusion of $290 \mathrm{cM}$ out of the whole human genome. Ital J Neurol Sci 1997;18:277-82.

31. Jonsson EG, Nothen MM, Gustavsson JP, Neidt H, Bunzel R, Propping P, et al. Polymorphisms in the dopamine, serotonin and norepinephrine transporter genes and their relationships to monoamine metabolite concentrations in CSF of healthy volunteers. Psychiatry Res 1998;79:1-9.

32. Ohara K, Suzuki Y, Ochiai M, Tsukamoto T, Tani K, Ohara K. A variable number tandem repeat of the serotonin transporter gene and anxiety disorders. Prog Neurol Psychopharmacol Biol Psychiatry 1999;23: 55-65.

33. Holroyd KA, Stensland M, Lipchik GL, Hill KR, O'Donnell FS, Cordingley G. Psychosocial correlates and impact of chronic tension-type headaches. Headache 2000;40:3-16.

34. Mitsikostas DD, Thomas AM. Comorbidity of headache and depressive disorders. Cephalalgia 1999;19:211-7.

35. Ogilvie AD, Russell MB, Dhall P, Battersby S, Ulrich V, Smith CA, \&al. Altered allelic distributions of the serotonin transporter gene in migraine without aura and migraine with aura. Cephalgia 1998;18:23-6.

36. Hranilovic D, Stefulj J, Schwab S, Borrmann-Hassenbach M, Albus M, Jernej B, \& al. Serotonin transporter promoter and intron 2 polymorphisms: Relationship between allelic variants and gene expression. Biol Psychiatry 2004;55:1090-4.

Accepted on 12-03-2008

Source of Support: Nil, Conflict of Interest: None declared.

\section{Author Help: Reference checking facility}

The manuscript system (www.journalonweb.com) allows the authors to check and verify the accuracy and style of references. The tool checks the references with PubM ed as per a predefined style. Authors are encouraged to use this facility before submitting articles to the journal.

- The style as w ell as bibliographic elements should be $100 \%$ accurate to get the references verified from the system. A single spelling error or addition of issue number / month of publication will lead to error to verifying the reference.

- Example of a correct style Sheahan P, O'leary G, Lee G, Fitzgibbon J . Cystic cervical metastases: Incidence and diagnosis using fine needle aspiration biopsy. Otolaryngol Head Neck Surg 2002;127:294-8.

- Only the references from journals indexed in PubMed would be checked.

- $\quad$ Enter each reference in new line, without a serial number.

- Add up to a maximum 15 reference at time.

- If the reference is correct for its bibliographic elements and punctuations, it will be shown as CORRECT and a link to the correct article in PubMed will be given.

- If any of the bibliographic elements are missing, incorrect or extra (such as issue number), it will be shown as INCORRECT and link to possible articles in PubM ed will be given. 